\title{
Public-Private Partnership for achieving sustainable development goals: a case study of Khulna, Bangladesh
}

\author{
Md. Nazmul Haque, Mustafa Saroar, Md. Abdul Fattah and \\ Syed Riad Morshed \\ Khulna University of Engineering \& Technology, Khulna, Bangladesh
}

achieving SDG in Bangladesh

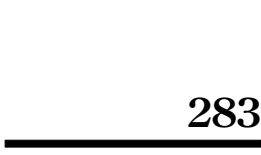

Received 6 May 2020 Revised 22 June 2020 Accepted 18 September 2020

\begin{abstract}
Purpose - Public-Private Partnership (PPP) is a common practice in both the public and private sectors. PPP has been an important instrument to achieve Sustainable Development Goals (SDGs) at the national level. However, the role of PPP at the subnational level is often scarcely studied. Using Khulna city of Bangladesh as a case, this paper aims to assess the role of PPP projects in the attainment of SDGs.

Design/methodology/approach - The research was conducted in the Central Business District (CBD) of Khulna, on a total of 4.6 kilometers stretches of road medians in the CBD where landscaping was done through the PPP approach. Besides the collection of secondary data from official records, primary data were collected through site visits, field surveys and interviews of PPP project partners.

Findings - The result shows that 89 percent of the respondents (road users) were pleased with the landscaping done on the road medians. Similarly, about 86 percent of the respondents felt more comfortable and safer to use the roads. Well-maintained road medians allow road-crossing at a regular interval which reduces the chance of an accident. The private parties have installed promotional billboards on the road medians and saved BDT 10.82 million a year. The public authority saves the maintenance budget amounting to BDT 23 million a year. The project achieves a triplewin situation. Despite some limitations, this PPP project has taken Khulna a step forward to achieve SDGs.

Originality/value - The findings have policy implications as the PPP project has enhanced the resilience of Khulna by addressing the relevant SDGs.
\end{abstract}

Keywords Public-Private Partnership, Resilient city, Sustainable Development Goals, Khulna

Paper type Research paper

\section{Introduction}

Humanity is approaching very fast toward an urbanizing world (UNFPA, 2007). About 55 percent of the global population became urban in the year 2018. By 2030, of the 5.2 billion city dwellers in the world, 2.8 billion will be in the Asia-Pacific cities (UNPD, 2018). The AsiaPacific region has experienced an unprecedented pace of urbanization over the last two decades or so (Dahiya and Das, 2020). As the urban areas account for 70 percent of the global Gross Domestic Product (GDP) and with the increased pace of urbanization, the Asia-Pacific region experienced sustained economic growth (UN-Habitat, 2016a). The cities have played a

(C) Md. Nazmul Haque, Mustafa Saroar, Md. Abdul Fattah and Syed Riad Morshed. Published in Public Administration and Policy. Published by Emerald Publishing Limited. This article is published under the Creative Commons Attribution (CC BY4.0) license. Anyone may reproduce, distribute, translate and create derivative works of this article (for both commercial and non-commercial purposes), subject to full attribution to the original publication and authors. The full terms of this license may be seen at http:// creativecommons.org/licences/by/4.0/legalcode

The authors are grateful to the officials of the KCC, RHD, KDA, local promotional agents of Grameen phone, Banglalink, and KSRM for their help with the secondary data. The authors are also thankful to B.U. Riyadh and S.B. Ansar for their cooperation during the field survey. Finally, the authors gratefully acknowledge the anonymous reviewers for their very constructive comments.

\section{HKPAA}

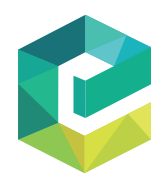

Public Administration and Policy Vol. 23 No. 3, 2020 pp. $283-298$ Emerald Publishing Limited 1727-2645 DOI 10.1108/PAP-04-2020-0023 
PAP

23,3

284

transformative role in the region, and are at the forefront of economic, social, political, and informational and technological change.

While cities become engines of economic growth, due to numerous reasons including the limited financial capacity of the governments to invest in social, economic and physical infrastructures in many countries, cities become a symbol of disparity in the provision of income, basic services and infrastructure development (UN-Habitat, 2016b; Dahiya and Das, 2020). For instance, governments in Asian countries would require US $\$ 4.7$ trillion over 10 years to meet urban infrastructure requirements, and an additional US $\$ 1.6$ trillion to replace aging infrastructure which is beyond the capacity of most of the countries (ADB, 2008; IMF, 2009). Without addressing urban issues and problems holistically, the attainment of Sustainable Development Goals (SDGs) would be even more difficult. Cities that manage their infrastructure and services well can maintain healthy living environments for their residents.

Accordingly, the United Nations (UN) has adopted the New Urban Agenda (NUA) which is intricately linked with the implementation of the 2030 Agenda for Sustainable Development (United Nations, 2015). The SDGs and targets, including Goal 11 - make cities and human settlements inclusive, safe, resilient and sustainable (United Nations, 2018) - can be achieved by building partnerships among actors operating at multiple levels and scales. Among various forms of partnerships to be discussed in this paper, Public-Private Partnership (PPP) is crucial to promote innovation, provide funding, technology, and transfer of knowledge and skills. Therefore, the partnership has appeared as an important vehicle for achieving SDGs related to urban issues and problems (UN-Habitat, 2016a).

Bangladesh has been experiencing a very fast pace of urbanization during the last four decades or so. Official statistics show that the percentage of the population living in urban areas has increased from about 9 to 32 percent during this period. However, according to the Agglomeration Index, an alternative measure of urban concentration, the share of Bangladesh's population living in areas with urban characteristics in 2010 was 45.7 percent. This suggests that there exists considerable hidden urbanization in Bangladesh (The World Bank, 2016). It is estimated that well ahead of 2050 more than 50 percent population will be living in areas having urban characteristics. That is about 120 million people living in urban areas. Although Bangladesh has 570 urban centers, only 25 cities are having over 100,000 (one hundred thousand) population. The major concentration of urban population is observed in Megacity Dhaka and the other three metropolitan cities (populations over one million).

Urbanization in Bangladesh is due primarily to push-pull factors. The capital city Dhaka and other three metropolitan cities such as Chittagong, Khulna, and Rajshahi are the main destinations of migrants from the rest of the country. This huge influx of internal migration in these four major cities is largely attributed to the economic and other roles played by these cities. The contribution of urban areas in Bangladesh's National GDP is about 70 percent, half of which generates from Dhaka city alone (The World Bank, 2013). The massive pressure exerted by the increased number of the urban population is manifold and extremely critical. Particularly high density, poorly developed water, sanitation, drainage, and waste management infrastructures and inadequate social and physical infrastructures including city-road networks have posed a formidable challenge to attain SDG 11, which aims for a safer, resilient and sustainable city.

To overcome the challenges posed by the fast pace of urbanization, there is a need for coordinated effort under long term investment planning. According to a World Bank 2013 study, the Milken Institute (2014) cites that, by 2020, the government of Bangladesh has to spend US $\$ 7.4$ to US $\$ 10$ billion a year to improve its power grids, roads, and water supplies to support its growing population. Only the transport sector will require investment in the range of US $\$ 36$ to US $\$ 45$ billion by 2020 . It is very unlikely to have such big investment for infrastructure development from the government budget as it will divert limited resources from other priority sectors such as water and sanitation, education, health and rural development (Gurara et al., 2018). Based on the experience of Latin America, Caribbean countries, and East-Asia, 
Bangladesh could explore the potential of PPPs for closing the rising funding gap in infrastructure investment (United Nations, 2013; Dewulf and Garvin, 2020).

Bangladesh's government in cooperation with many multilateral, bilateral agencies/ institutions, private sector, and non-government organizations (NGOs) has implemented many programs and projects to attain the SDGs. The role of the private sector has been very instrumental in certain types of investment projects (Rashed et al., 2014). The central government could leverage its revenue generation power and authority. Over the decades, it has attracted finance from the private sector under the PPP model. About $72 \mathrm{PPP}$ projects at different stages of development and delivery have been undertaken by the Bangladesh government in the areas of energy, transport, port, water supply, real estate, tourism, and health, many of which are transnational investments. Investment under the PPP model has reached about US $\$ 22.7$ billion by the fiscal year 2018-19. Bangladesh has experienced the three phases of PPP and institutionalized clear guidelines for PPP (Public Private Partnership Authority Bangladesh, 2019).

Despite a large number of PPP projects under the central government, very few PPP projects are under the local government such as the City Corporation or municipality. As the local government revenue base is still weak, PPP could help the financing of the various innovative projects with the attainment of SDGs. However, most of the PPP projects under the local government unit (City Corporation) are confined to solid and clinical waste management. Recently four large City Corporations such as Dhaka, Chittagong, Khulna, and Rajshahi have initiated the beautification and (minor) maintenance of city-roads projects under the PPP/quasi-PPP model. Although PPP projects under local government are gaining popularity, there is a scarcity of research that has systematically appraised PPP projects of local government in the transport sector.

Literature reveals that a large majority of the recent research have investigated the challenges of PPP projects in various contexts (Nguyen and Garvin, 2016; Agarchand and Laishram, 2017; Dewulf and Garvin, 2020). Sajan et al. (2014) and Rashed et al. (2014) critically analyzed the policy framework of PPP in Bangladesh. Similarly, the ILO (2019) study analyzed the impacts of PPP projects in the labor sector. Very scanty of empirical research has been conducted to appraise PPP in a local context. The only exceptions are Abedin (2010) and WSUP (2017) who have examined the health benefit of the water and sanitation projects on the poor city dwellers. No study has appraised the beautification and maintenance of the city-roads project of City Corporation taken under the PPP model.

This study fills this research gap in three ways. First, it examines the institutional arrangement of PPP project in beautification and maintenance of city-roads; second, it investigates the role of the PPP project in attaining the SDG 11 with particular focus on city resilience, economic efficiency, comfort and safety of the city dwellers. Finally, it identifies the local challenges that PPP project encounters and gives policy suggestions to better address the problems to help attain the SDGs.

\section{A succinct review of the theory and models of PPP with SDGs}

Partnership as a concept implies joint and voluntary endeavors toward a common purpose. Therefore, the partnership is about sharing power, responsibility, and achievements (Farazmand, 2018). Harriss (2000) conceptualized partnership as a kind of relationship between individuals and groups to accomplish a common goal. The United Nations framed partnerships as voluntary and collaborative relationships between various parties to achieve a common purpose (United Nations, 2015). Partnerships enable the sharing of experiences, knowledge, skills, technology, and financial resources to materialize concrete actions for sustainable development. Farazmand (2004) has outlined five partnership models including the autonomous model, the independence model, the globalization-convergence model, the hybrid

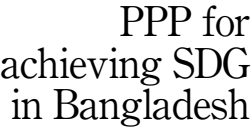

285 
PAP

23,3

286

model, and the elite model. Each of these models includes alternative premises, strategies and global frameworks. However, the bedrock elements of any form of a partnership are mutual dependence, respect, and trust, as well as accountability and transparency (Farazmand, 2004). Therefore, partnerships can take many forms of collaboration; partnerships with businesses, academia, NGOs, and international organizations.

Among various forms of partnership, the PPP approach of collaboration has been gaining popularity since 1990 (Brinkerhoff, 2002). The partnership is one of the five thematic areas identified in the Preamble of the Agenda 2030: People, Planet, Prosperity, Peace, and Partnership - known as the 5 Ps of the SDGs. There are various models of PPP each reflecting the characteristics of the partnership agreement (Farazmand, 2018). For all models of PPP, it is believed that PPP would (a) improve the quality and the performance of public services to the benefit of users/consumers; (b) reduce or, at least, ease the time-profile of the tax-payers' burden; (c) help the public authorities, which are responsible for delivery of the services, to optimize the realization and quality of those services (The World Bank, 2012).

The PPP is expected to complement governments' efforts at the national and subnational/ local levels (Sunam et al., 2018). Developing state-NGO partnerships to ensure the delivery of basic social services to all in the developing world is integral to contemporary development thinking (Joshi and Moore, 2004). The government of Bangladesh has introduced PPP in 1996 after approving the private sector power generation policy of Bangladesh (Rashed et al., 2014) to facilitate the development of public infrastructure and services. The present government has reinforced the PPP with the policy guideline to help achieve relevant goals of the Vision 2021 aligned with the Global Agenda 2030 (Public Private Partnership Authority Bangladesh, 2019). Since the introduction of PPP in 2009, many private entities have been working together with the public authority and contributing to improve water supply, sanitation, health, environment, energy, and physical infrastructure all aimed at achieving the SDGs in Bangladesh.

\section{Study area}

Khulna is one of the four major cities in Bangladesh which has more than one million populations. The government body, Khulna City Corporation (KCC) has developed the city, locating on the bank of Bhairab-Rupsha River, as the main center of trade, commerce, industry, administration, health, and education in the southwest region for a half-century. Khulna is well connected with the capital city Dhaka and other regional cities with a multimodal transport system (rail, road, water, and air transport). As this city offers all kinds of city services and has a well-developed transportation network, a huge influx of people from nearby cities has created enormous pressure on services and infrastructures provided by the city authority (Haque et al., 2019). In Khulna, the total number of various types of all-weather roads is about 1215 of which about 80 kilometers are major roads, with width ranging from 10 to 25 meters (two-lane and four-lane road). These major roads are located around and directed to the city core area/ city center. Every day, about 15,000 motorized transport (mostly slowmoving small vehicles) ply along these roads. Apart from the transport of goods and services, about 100,000 city dwellers and commenters use these roads every day.

The major roads are usually constructed by the Roads and Highways Department (RHD) and the Khulna Development Authority (KDA) in Khulna; however, the portion of all types of roads (except national highway) that are within the city corporation area has to be maintained by the city corporation. Like most local governments in developing countries, the Khulna government (KCC) often faces serious budgetary pressure to construct, expand, and maintain the services and infrastructures required for the livable city environment. Particularly, the major roads encounter massive pressure from the increased volume of traffic and seasonal waterlogging resulted from poorly managed drainage networks along the major roads (Haque et al., 2019). To ease the budgetary pressure and to ensure proper maintenance of 
streetscape along the road median of major roads, the $\mathrm{KCC}$ has entered a kind of PPP with private entities/businesses.

For this study among the major roads/ road segments that are bought under PPP for maintenance, only four major roads/ road segments such as the Jora gate intersection to Shibbari intersection (Khulna-Jessore Road), Shibbari intersection to Dakbangla intersection (Upper Jess ore Road), Shibbari intersection to Moylapota intersection (KDA Avenue Road), Shibbari intersection to Sonadange Bus terminal intersection (Majid Sarani Road) are selected based on their importance (Figure 1). These road/ road segments are within a one-kilometer radius of the main city center of Khulna where different government offices, public halls, public parks, wholesale markets, commercial establishments (banks, insurance, hotels, restaurants, and shopping malls), museums, hospitals/ clinics, railway station, and bus stations are located. Therefore, these road/ road segments generate all kinds of traffics (including pedestrians).

\section{Research methodology}

This study draws on a mixed method of research; it has used both qualitative and quantitative research protocols. Apart from these, literature concerning PPP in varied contexts is reviewed to have a solid basis for positing findings of this research from a comparative perspective. Finally, office records from relevant departments of KCC, and private parties involved with the PPP process in Khulna are also consulted. Particularly the PPP contract-related documents, terms and conditions, and financial issues are examined. Initially, during January-February 2019, a reconnaissance survey was done in each of the road segments to get familiarized. Later more in-depth information about the technical specification of the road median trips, type of landscaping elements used, routine maintenance and plan for improvements of the landscaping in the road medians,

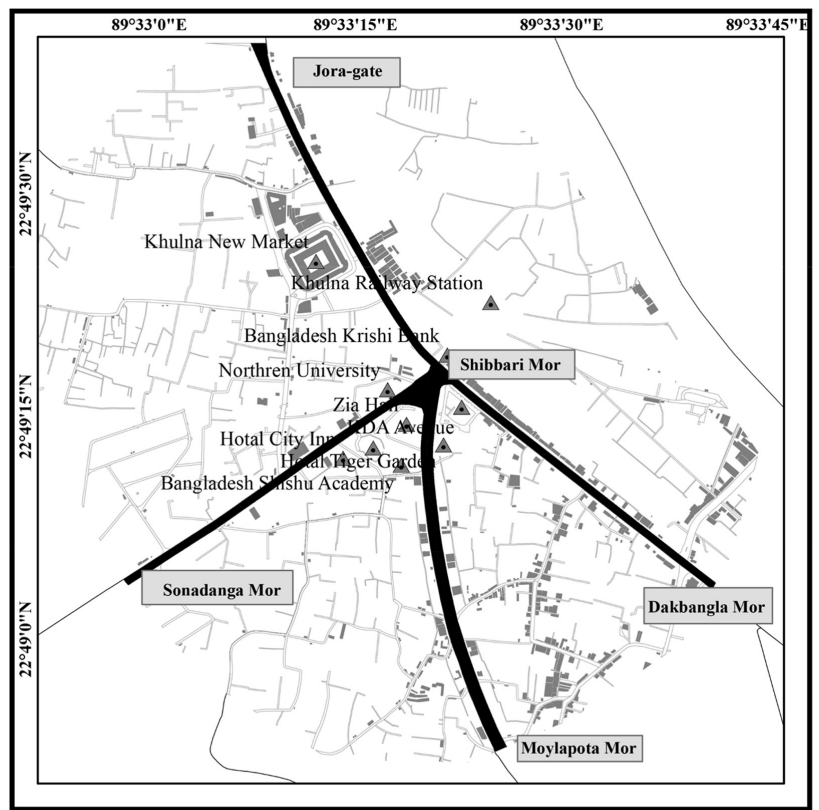

Source: By authors (2020)

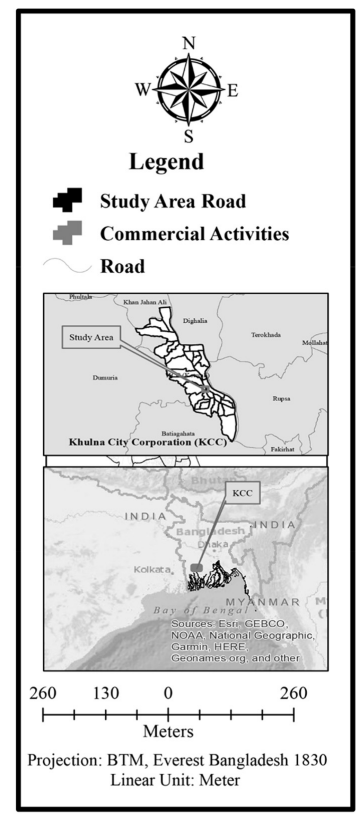
Map of the study area Khulna, Bangladesh achieving SDG in Bangladesh 
PAP

23,3

288

promotional billboards use in the road medians, the challenges of ongoing PPP, etc. are obtained through close consultation with the relevant personnel from KCC, and the local promotional agents of Grameen phone mobile operator, Banglalink mobile operator, and Kabir Steel Re-rolling Mills (KSRM).

Apart from the above, a short questionnaire survey was conducted among 215 road users selected randomly in the month of February-March to explore how the road users appraised the various aspects of PPP-based landscaping in the road median project. However, while selecting the respondents for the survey, high emphasis was given to pedestrians, drivers, employees of commercial enterprises, and office workers whose workplaces were located around the road segments studied and who used the road segments regularly. In the survey, along with other questions such as the changes in cleanliness, aesthetic quality, walkability, and traffic-flow, etc. the main emphasis was on the following aspects.

- If they are satisfied with the quality of landscape elements and their maintenance;

- If they feel more comfortable/ safer and secure to use these roads than earlier when the landscaping project was not done;

Finally, qualitative data were grouped to form some patterns for analysis. Financial data were used to come up with a kind of cost-benefit analysis of PPP projects, and survey questionnaire data were analyzed through excel spreadsheets. Moreover, the illustrative figures (photos, maps, graphs) and tables are used to aid the result and discussion section.

\section{Results and discussion}

Institutional aspects and nature of PPP in Khulna

In line with the SDG 11 (make cities and human settlements inclusive, safe, resilient and sustainable), the KCC has been making its best effort to make Khulna an ideal place for living and working. To make the city environment livable, the city authority has to ensure proper maintenance of its various physical infrastructures including drainage and transportation network in the city. Conventionally, KCC implements a 5-year project from government funding every five years. Most parts of the financing are for new road construction and drainage network development in the expanded area of the city. Only a very insignificant share of investment goes to the maintenance of existing roads. Road maintenance fund is used for engineering and civil construction-related activities such as carpeting of damaged road surface, repair of footpaths and walkways, repair of street lighting, etc. Maintenance of streetscape, roadside plantation, landscaping along the median strip of major roads have been always neglected issues due to budget constraints. For a safer, resilient and sustainable city, there is a strong need for landscaping of street elements including its median strips because it offers not only aesthetics, but more importantly, it regulates microclimate (temperature control), regulates waterlogging (by increasing infiltration), prevents topsoil erosion (of road median), and provides a pleasant environment for road users (Leal Filho et al., 2019).

Among a total of 30 kilometers road that has wide road median, about 20 kilometers road where the width of road median is more than 1.5 meters has been brought under landscaping. Part of the road median landscaping is done under the City Region Development Project (CRDP I) which was mostly financed by the donor, GIZ. Landscaping in road median strips of other roads has been done in partnership with private enterprises. The landscaping in the road median strips in the five study roads/ road segments has been done by the local promotional agents of private companies such as Grameen phone mobile operator, Banglalink mobile operator, Kabir Steel Re-rolling Mills (KSRM) under a contractual arrangement. They got the contract through unsolicited application for rendering the landscaping service for a fee. As per the contract the $\mathrm{KCC}$ has handed over the road medians 
to the promotional agents of these companies. These companies' agents are allowed to alter the landform inside the median strips for landscaping. They have planted both local and exotic varieties of tree, shrub, and grass. The companies' agents have employed outsourced workers for planting, watering, and pruning of the plantation in the median strips. In the study, road/ road segments government authorities such as KCC, KDA and RHD have constructed the median. The private companies' agents have developed the median and made the landscape of the median strips aesthetically more appealing (Figures 2-4). Particularly the shrubs planted on the median strip of the KDA avenue road catch the attention of the road users for their iconic beauty.

City residents' perception of the benefits of PPP projects

As mentioned in the methodology section, a public perception/ satisfaction survey was conducted to understand the perceptions of road users about the benefits of PPP projects on

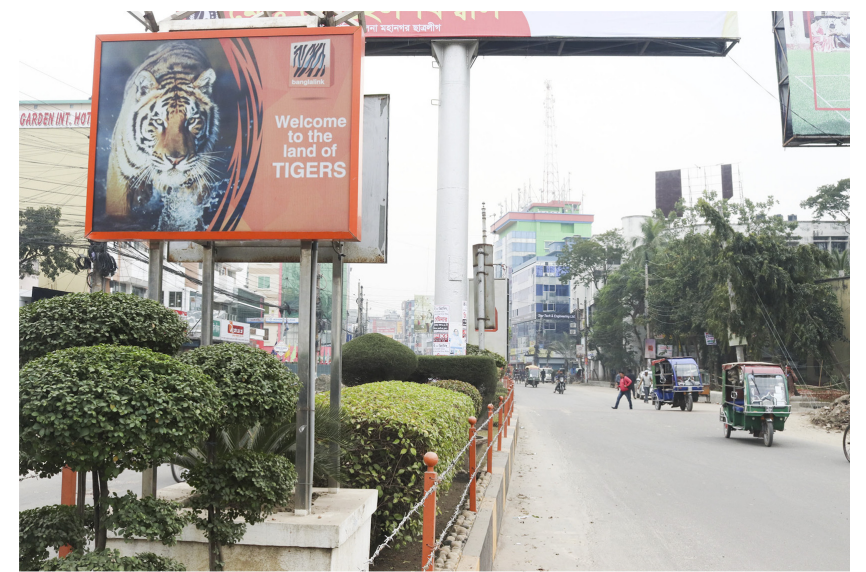

Source: Field survey in 2019

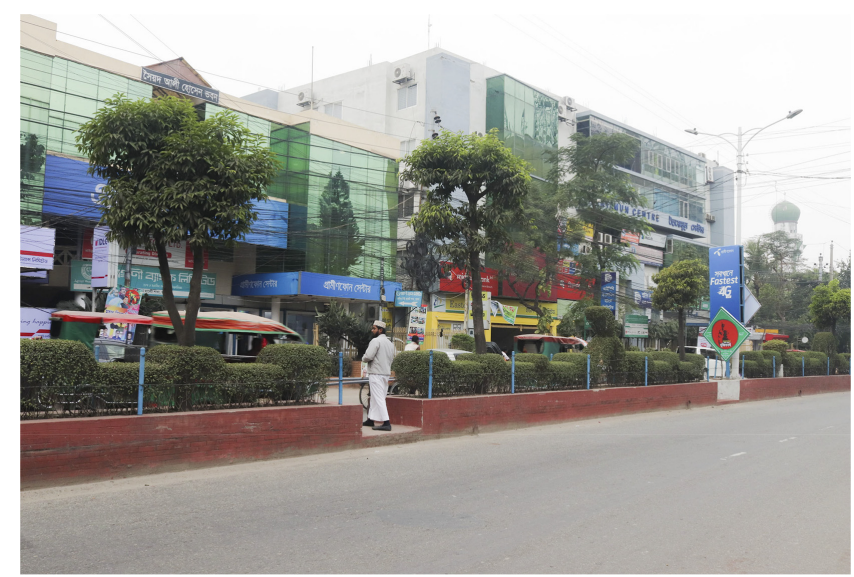

Source: Field survey in 2019

\section{PPP for achieving SDG in Bangladesh}

289
Figure 2.

Landscaping done in the median strips of KDA Avenue road (Shibbari intersection to Moylapota intersection) under the PPP project in Khulna
Figure 3.

Landscaping of road median strips under PPP project in Khulna offered long interval cross-walk which helped change habit of frequent road-crossing 


\section{PAP \\ 23,3}

290

Figure 4.

Landscaping of road median strips under PPP project in Khulna offered clean and green corridor

Figure 5.

Road users' assessment of various beneficial aspects of the landscaping of road median strip projects under PPP approach

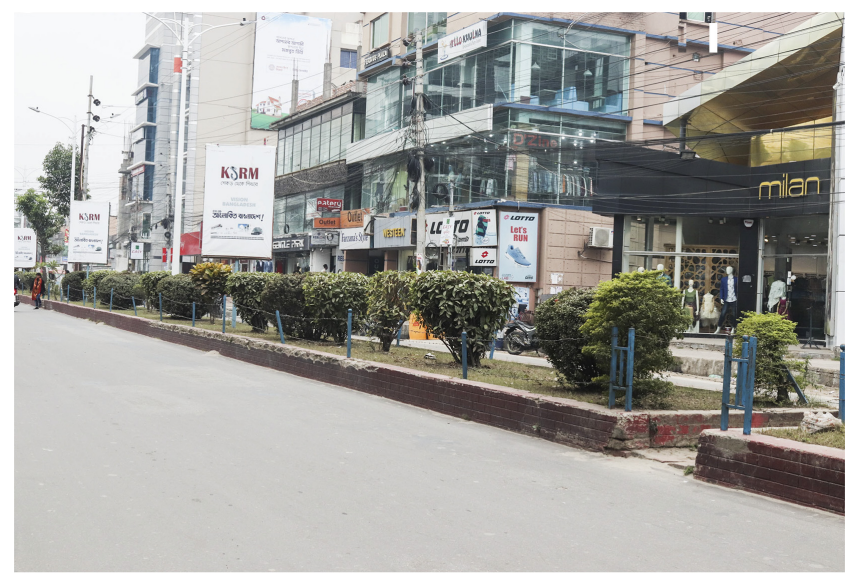

Source: Field survey in 2019

the landscaping of road median strips in Khulna. They were asked to respond to four possible benefits from this project listed as follows. Their responses were coded in binary format (yes or no).

- If they are satisfied with the quality of landscape element provided along the median strips of the roads;

- If they are satisfied with the quality of maintenance of the landscaping done along the median strips of the roads;

- If they feel more comfortable/ safer to use these roads than earlier when the landscaping project was not done;

- If they feel more secure to use these roads particularly at night than earlier when the landscaping project was not done.

Their responses are summarized in Figure 5. Figure 5 reveals that about 89 percent of road users are satisfied with the quality of landscape elements used in the road median strips. The satisfaction of a very high number of respondents could be attributed to the greenery and the pleasant environment that the landscaping in the median strips offers. For landscaping,

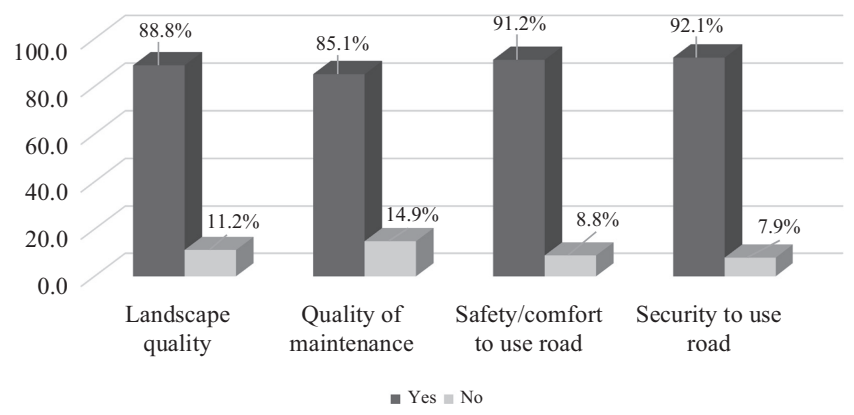

Source: By authors (2020) 
different types of plants, shrubs, flowering trees, and creeper plants have been planted which has increased the aesthetic quality of these road segments. Consultation with company representatives reveals that their appointed staff/ workers regularly do replanting (when necessary), watering, and pruning of the landscaping elements. This also has contributed to reducing environmental pollution such as noise and dust-blown pollution along the streets. As regards the quality of maintenance of the landscaping, about 85 percent of respondents have shown their satisfaction. A high proportion of satisfaction about the maintenance of landscaping could be related to private companies' effort to maintain regularly. Company representatives have claimed that their appointed staff/ workers repair, clean, and decorate the median strips apart from taking care of the greeneries regularly. Therefore, these road segments are seen as much cleaner than other roads in Khulna (Figures 2-4).

Landscaping in the median strips screens out the glare of headlights coming from the opposite direction which has increased the comfort of the road users, particularly at night time. About 91 percent of respondents have acknowledged that they feel more comfortable/ safer to use the roads than they used to feel before the project implementation. Moreover, as the median trips work as a physical barrier, the road-crossing behavior of pedestrians has been changed a lot. This has ensured the smooth flow of vehicular traffics and reduced the rate of accidents. Finally, about 92 percent of respondents have mentioned that they feel more secure to use the roads after the implementation of the landscaping in the road median trip project under PPP. Perception about increased security of road users particularly at night is attributed to a few reasons. First, to beautify the landscaping, the companies have installed garden lighting arrangements along the median strips. Second, to promote their products and services, the companies have installed digital billboards having high power led lights. These two lighting arrangements have increased the visibility all along the road corridors. Therefore, road users feel more secure from the threat of snatching/ hijacking during the night time. Because of the numerous benefits that the regular road users get from the landscaping of road median trips under the PPP project, about 86 percent of respondents are very satisfied and 10 percent are moderately satisfied with the project. Only 4 percent are not satisfied with the project (Figure 6).

\section{Public sector's benefit from the collaboration}

The function of public authority in PPP is to create opportunities for private entities to invest so that they can serve the nation without compromising with their company's interests. In

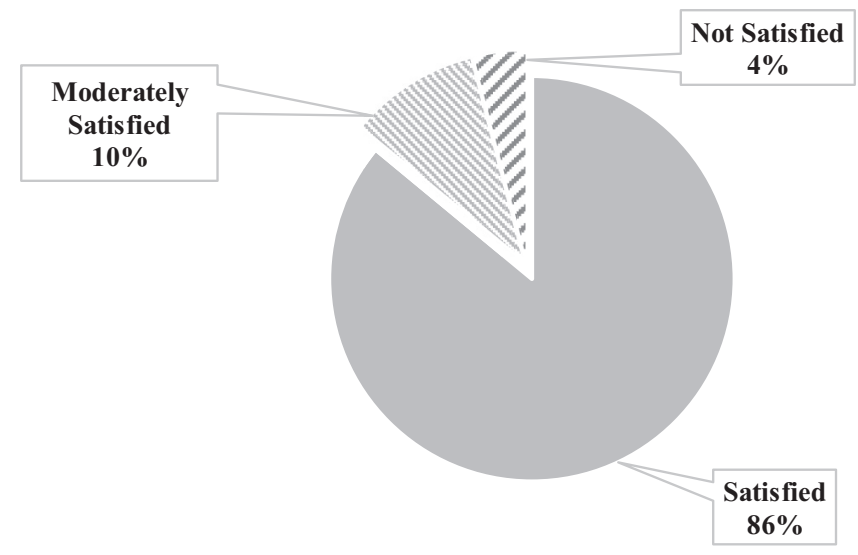

Source: By authors (2020)

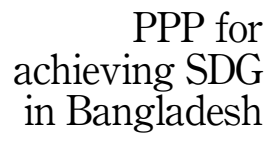

291
Figure 6.

Road users' level of satisfaction about the outcome of the landscaping of road median strip project under PPP approach 
PAP

23,3

292

Khulna, government agencies such as KDA and RHD have constructed road medians in some road segments within the city. However, maintenance of these roads (except national highway) in the city rests with the KCC. The internal revenue base of KCC is not very sound and the Annual Development Programme (ADP) allocation receives from the government is highly variable due to political reasons. For instance, if the elected Mayor of the KCC is from the ruling party, $\mathrm{ADP}$ allocation is different as compared when the Mayor is from the opposition party. During 2009-2015, Mayor was from the ruling party, and KCC constructed about 205 kilometers long new metal/ all-weather roads. However, the maintenance budget is always very low; to overcome this, $\mathrm{KCC}$ has initiated PPP projects for maintenance of about 5 kilometers road median strips.

In the financial year 2018-2019, from the PPP project partners (private companies), KCC has received about half a million BDT as tax. Moreover, as the project partner companies have invested for maintenance of the road median trips under the PPP, this has helped KCC to save about BDT 2.3 million (original allocation for road median maintenance) in a year. The KCC's allocation was BDT 5000 for the maintenance of every 1-meter of road median in Khulna. If the PPP project could be implemented in all roads' medians in Khulna which is about 20 kilometers long, this would have saved about BDT 100 million in a year from KCC's earning (Table 1).

A planned expansion of this type of partnership in other working areas/ sectors of KCC such as waste management, health and sanitation, slum improvement, and recreation facility development could further help to reduce the expenditure of KCC. However, the government must develop a policy framework for the private sector to collaborate with local government on a sustained basis which would help the local government like KCC to achieve the SDGs within 2030.

\section{Private sector's benefit from the collaboration}

Every year, private companies spend billions of dollars for promoting their name and fame, goods to boast up their revenues. They use various platforms and media including billboards

\begin{tabular}{|c|c|c|c|c|c|}
\hline Road Name (c1) & $\begin{array}{l}\text { Length of } \\
\text { road } \\
\text { median } \\
(\mathrm{km})(\mathrm{c} 2)\end{array}$ & $\begin{array}{l}\text { Tax rate per } \\
\text { meter length } \\
\text { of road } \\
\text { median } \\
\text { (BDT) }(\mathrm{c} 3)\end{array}$ & $\begin{array}{c}\text { Under PPP } \\
\text { revenuer earns } \\
\text { from companies } \\
\text { per year (BDT) } \\
(\mathrm{c} 4=\mathrm{c} 3 * \mathrm{c} 2)\end{array}$ & $\begin{array}{c}\text { Budget for } \\
\text { Maintenance per } \\
\text { year (BDT) } \\
\left(\mathrm{c} 5=5,000^{*} \mathrm{c} 2\right)\end{array}$ & $\begin{array}{l}\text { Net benefit of } \\
\text { KCC (BDT) } \\
(\mathrm{c} 6=\mathrm{c} 4+\mathrm{c} 5)\end{array}$ \\
\hline $\begin{array}{l}\text { Jora-gate } \\
\text { intersection to } \\
\text { Shibbari } \\
\text { intersection }\end{array}$ & 0.90 & 150.00 & 135,000 & $45,00,000$ & $4,635,000$ \\
\hline $\begin{array}{l}\text { Shibbari } \\
\text { intersection to } \\
\text { Moylapota } \\
\text { intersection }\end{array}$ & 1.20 & 150.00 & 180,000 & $60,00,000$ & $6,180,000$ \\
\hline $\begin{array}{l}\text { Shibbari } \\
\text { intersection to } \\
\text { Sonadanga bus } \\
\text { stand }\end{array}$ & 1.20 & 55.00 & 66,000 & $60,00,000$ & $6,066,000$ \\
\hline $\begin{array}{l}\text { Shibbari } \\
\text { intersection to } \\
\text { Dakbangla } \\
\text { intersection }\end{array}$ & 1.30 & 77.00 & 100,100 & $65,00,000$ & $6,600,100$ \\
\hline Total & 4.6 & . & 481,100 & $2,30,00,000$ & $23,481,100$ \\
\hline \multicolumn{6}{|c|}{ Source: By authors (2020) } \\
\hline
\end{tabular}

Table 1. 
for the promotional campaigns of their products and services. Under the PPP project studied in Khulna, private companies like mobile operator Grameen phone, Banglalink, and stainlesssteel manufacturer KSRM have been using modern billboards placed/ installed in the road median to promote their products and services. According to the private companies, in absence of PPP type collaboration, they would have to pay an average BDT 6500 per meter of road median use for promotional purposes.

As there are many important establishments and buildings such as New Market (main shopping district), KDA building, high-end hotels, restaurants, banks, insurances, hospital, clinics, electronics markets, shopping malls and varieties of commercial buildings situated along the road connecting Jora gate intersection with Moylapota intersection, the advertisement cost is more in this road. Table 2 shows that for promoting advertisements in the road medians, the private companies would have to pay BDT 29.7 million as tax each year. Under the PPP, as the private companies' local agents have taken the responsibility of the maintenance of the road medians, they pay a relatively very little amount to the government as tax (Table 1). Leveraging the PPP, the private companies are jointly spending about BDT 18.9 million each year for the maintenance of the road medians and in return using the road medians for promotional purposes. This PPP has helped them save about BDT 10.8 million in a year (Table 2). This huge reduction of promotional expenses of the private authorities might encourage them to collaborate further for the expansion of this project or doing closely related PPP projects in Khulna.

The analysis shows that apart from public benefits, the PPP model at the local level has created a win-win situation for the public authority and private companies as well. Long-term collaboration could improve the quality of the environment in the study roads in Khulna city on a sustainable basis which would help to enhance the livability in Khulna and ultimately

\begin{tabular}{|c|c|c|c|c|c|c|c|}
\hline $\begin{array}{l}\text { Road Name } \\
\text { (c1) }\end{array}$ & $\begin{array}{l}\text { Length } \\
\text { of road } \\
\text { median } \\
(\mathrm{km})(\mathrm{c} 2)\end{array}$ & $\begin{array}{l}\text { Under } \\
\text { PPP tax } \\
\text { paid to } \\
\text { KCC for } \\
\text { use of } \\
\text { road } \\
\text { median } \\
\text { (BDT) (c3) }\end{array}$ & $\begin{array}{c}\text { Under PPP } \\
\text { operation \& } \\
\text { maintenance } \\
\text { cost of } \\
\text { companies per } \\
\text { year (BDT) (c4) }\end{array}$ & $\begin{array}{l}\text { Under PPP } \\
\text { total project } \\
\text { expenditure of } \\
\text { companies per } \\
\text { year (BDT) } \\
(\mathrm{c} 5=\mathrm{c} 3+\mathrm{c} 4)\end{array}$ & $\begin{array}{l}\text { Without PPP } \\
\text { companies had } \\
\text { to pay per year if } \\
\text { they wanted to } \\
\text { use road median } \\
\text { for promotional } \\
\text { purposes (BDT) } \\
\text { (c6) }\end{array}$ & $\begin{array}{l}\text { Under PPP } \\
\text { net gain of } \\
\text { companies } \\
\text { per year } \\
\text { (BDT) } \\
(\mathrm{c} 7=\mathrm{c} 6-\mathrm{c} 5) \\
\end{array}$ & \\
\hline $\begin{array}{l}\text { Jora-gate } \\
\text { intersection } \\
\text { to Shibbari } \\
\text { intersection }\end{array}$ & 0.90 & 135,000 & $36,00,000$ & $37,35,000$ & $63,00,000$ & $25,65,000$ & \\
\hline $\begin{array}{l}\text { Shibbari } \\
\text { intersection } \\
\text { to Moylapota } \\
\text { intersection }\end{array}$ & 1.20 & 180,000 & $48,00,000$ & $49,80,000$ & $84,00,000$ & $34,20,000$ & \\
\hline $\begin{array}{l}\text { Shibbari } \\
\text { intersection } \\
\text { to Sonadanga } \\
\text { bus stand }\end{array}$ & 1.20 & 66,000 & $48,00,000$ & $48,66,000$ & $72,00,000$ & $23,34,000$ & \\
\hline $\begin{array}{l}\text { Shibbari } \\
\text { intersection }\end{array}$ & 1.30 & 100,100 & $52,00,000$ & $53,00,100$ & $78,00,000$ & $24,99,900$ & \\
\hline $\begin{array}{l}\text { to Dakbangla } \\
\text { intersection } \\
\text { Total }\end{array}$ & 4.6 & 481,100 & $184,00,000$ & $188,81,100$ & $297,00,000$ & $108,18,900$ & $\begin{array}{l}\text { Table } 2 . \\
\text { Appraisal of the benefit } \\
\text { of private parties from }\end{array}$ \\
\hline \multicolumn{7}{|c|}{ Source: By authors (2020) } & PPP project \\
\hline
\end{tabular}


PAP

23,3

294

contribute to the attainment of the SDG 11 . The whole study findings could be summarized through the following graphical presentation (Figure 7).

Figure 7 shows that the PPP project has opened up new avenues of collaboration between the local public authority and private parties. The local public authority provides infrastructures and exercises regulatory control. The private companies upgrade the services/ infrastructures provided by public authority and ensure their maintenance. The collaboration offers a triple-win situation: (a) city residents enjoy clean and green transport corridors, safety and security while using the roads; (b) the city authority maintains wellfunctioning streets without incurring cost from its revenue; and (c) the private parties achieve cost advantage to promote their products and services and to build a public image. The outcome of this PPP is moving forward to achieve resilient, safe and sustainable Khulna in line with SDG 11. At the heart of this triple-win outcome is the partnership strategy outlined in SDG 17. The SDG 17 emphasizes building partnerships across levels and sectors for achieving SDGs. By initiating this PPP project, Khulna city authority has shown its strong commitment to building partnerships with multiple actors including the private sector for leveraging the private sector's capacity to provide technology and finance.

\section{Challenges to PPP in Khulna}

Earlier it is seen that PPP projects in the study roads have contributed substantially toward the achievement of SDG 11 at the local level in Khulna. Based on the result of this study, policymakers might think of moving forward with this kind of PPP project covering larger areas in Khulna or elsewhere. However, a couple of challenges that the projects encounter have to be addressed on a priority basis in order to harness the full potential of this type of PPP project. The challenges are discussed as follows.

Figure 7.

The local operational model of PPP in Khulna to achieve SDGs

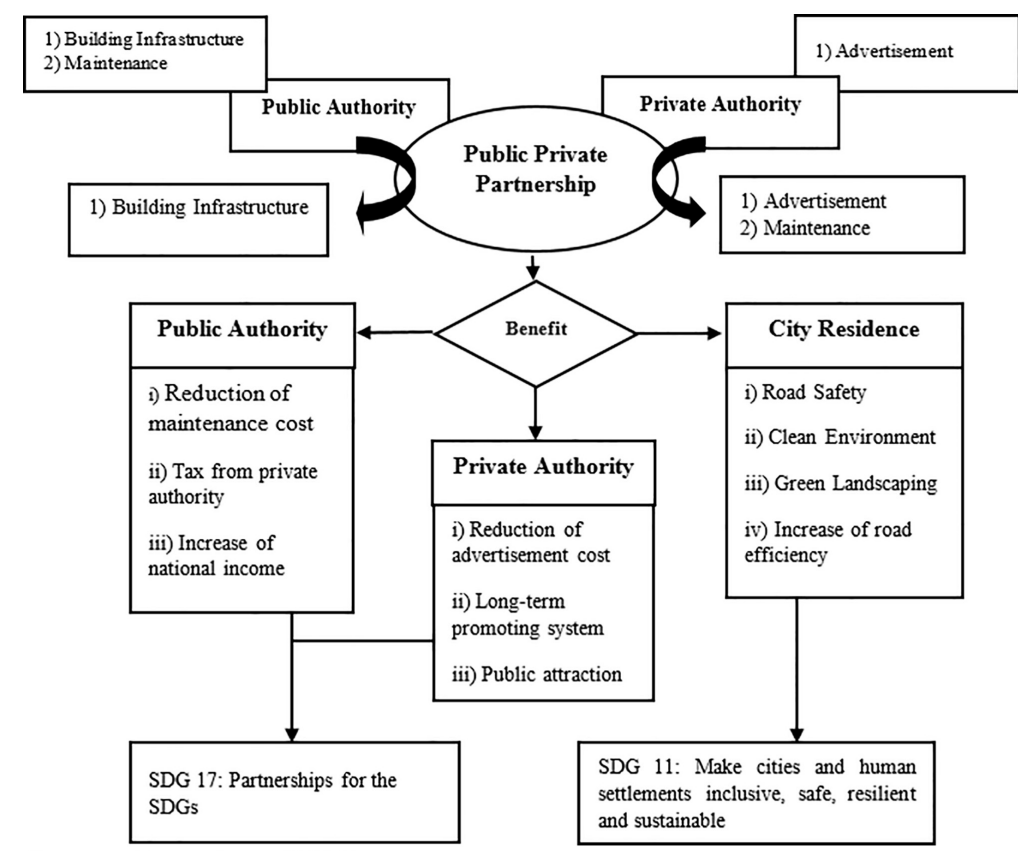

Source: By authors (2020) 
(1) The first challenge is related to the institutional framework. Until now KCC does not have any policy framework to work with a business entity for PPP types of collaboration in landscape improvement in road median. Everything is done on an ad hoc basis. This acts as an impediment for the private party to invest from a long-term perspective. To obtain results from any landscape development project, there is a need for certain years as planted trees/ shrubs take time to grow (Flemer III, 1984). Any big investment in a landscaping project of this scale requires a longer-term contract; however, in absence of a stable policy framework, it is less likely that private party would cooperate for any longer horizon as there exist huge uncertainty that the contract might not renew particularly where political process dominates over everything.

(2) The second challenge is that in the absence of an open, transparent and competitive tender procedure, parties making unsolicited applications and willing to pay the fee as per the government rate schedule (rate of per meter length of road median is determined by the government) are awarded the PPP contract for landscape improvement in road median. This is problematic for two reasons. First, if two or more parties approach the city authority for the same segment of road median, how the contract is awarded is not clear. Second, even when only one party makes an unsolicited application, the contract is awarded without opening the opportunities to other potential parties.

(3) The third challenge is the absence of any institutional monitoring system. In the absence of this kind of monitoring from the part of the regulating agency, the private party does its best to serve its interest. For instance, in every kilometer length of road median strip how many billboards could be installed is not specified in the contract; therefore, billboard outnumbered the landscaping element (assuming billboard is not a landscaping element).

(4) The fourth challenge is the specification of landscape elements. The landscaping is done as per the wish of the private party. There is no specification of plants, shrubs, creepers to be planted. This is important because, in a coastal climate, not all species of plants/ shrubs/ creepers provide the best environmental benefit for the city residents; some not even survive (Hasanuzzaman et al., 2014).

(5) The fifth challenge that has been emerged from this study is: KCC does not give specific guidelines about the density of plants/ shrubs to be planted in the road median strips. In humid subtropical areas, for single row plantation in road median, 333 plants per kilometer/ length are planted; this is done in India (Government of India, 2015). But in the study, road segments density of plantation (both shrub/ leafy low height tree/ palm tree) is very low in the count. There are several reasons for that; first, due to poor site condition (water logging in the root zone and salinity), the mortality rate is high but replacement is not done very often; second, the companies install small promotional billboards of their products and services in the road median strips; third, to increase the visibility of those billboards, they maintain a low density of plants/greeneries.

However, for installing the billboards, they beautify the road median through cleaning and visually appealing painting/ decoration. Therefore, the road users' survey revealed that the median strip of the study roads/ road segments were found much cleaner, greener, and nicer than other road medians in Khulna. The mobile phone operator Grameen phone's local promotional agent claimed that the paint is applied once every year in the median including cleaning twice a week. This initiative greatly reduced the government's responsibility for the 
maintenance of the median strips and influences the private sector to collaborate with the local government for achieving long-term environmental benefits in Khulna. Achieving this alone from the government budget is a difficult undertaking for KCC. In addition, to improve the transparency, instead of direct awarding the PPP contracts to selected agencies, open tendering procedures could be adopted.

\section{Conclusion}

The study has investigated the nature and role of PPP projects on the landscaping of road medians in Khulna of Bangladesh in achieving the SDG 11. The findings suggest that the project creates a triple-win situation. The city residents benefit from a clean and green environment, enjoy the safety and secure mobility along the landscaped road corridor. The collaborating private companies enjoy estimated benefits of BDT 10.82 million a year and the KCC saves about BDT 23 million a year. The implementation of PPP in all of the medians of Khulna roads will increase the revenue of the government and will increase the ecofriendliness of the road median in Khulna along with the increased road safety and safe pedestrian movement. The outcome of the analysis shows that public authority is benefitting the most due to PPP. The city residents are satisfied with the landscaping in the road median and its maintenance in Khulna. The research highlighted the significance of PPP to achieve SDGs and showed how impactful a local level PPP project can be on the public, governments, local economy and environment. Despite some challenges such as awarding PPP contracts without a competitive tendering process, this PPP project has taken Khulna a step forward to achieve SDGs. This study can serve as a reference for making a long-term sustainable plan for the implementation of PPP in road medians across the country. Finally, the outcome of this research could influence the policy-making process to make local level PPP success in many other sectors/ areas in Khulna or elsewhere to achieve SDGs.

\section{References}

Abedin, M.N. (2010), Public Private Partnership in Service Delivery: An Evaluation of Naional Sanitation Program of Bangladesh, Institute of Governance Studies, BRAC University, Dhaka.

ADB (Asian Development Bank) (2008), Strategy 2020: The Long Term Strategic Framework of the Asian Development Bank 2008-2020, Asian Development Bank, Manila.

Agarchand, N. and Laishram, B. (2017), "Sustainable infrastructure development challenges through PPP procurement process: Indian perspective", International Journal of Managing Projects in Business, Vol. 10 No. 3, pp. 642-662.

Brinkerhoff, J.M. (2002), "Government-nonprofit partnership: a defining framework", Public Administration and Development, Vol. 22 No. 1, pp. 19-30.

Dahiya, B. and Das, A. (2020), "New urban agenda in Asia-Pacific: governance for sustainable and inclusive cities", in Dahiya, B. and Das, A. (Eds.), New Urban Agenda in Asia-Pacific: Advances in 21st Century Human Settlements, Springer, Singapore.

Dewulf, G. and Garvin, M.J. (2020), "Responsive governance in PPP projects to manage uncertainty", Journal of Construction Management and Economics, Vol. 38 No. 4, pp. 383-397.

Farazmand, A. (2004), "Innovation in strategic human resource management: building capacity in the age of globalization", Public Organization Review, Vol. 4 No. 1, pp. 3-24.

Farazmand, A. (Ed.) (2018), Global Encyclopedia of Public Administration, Public Policy, and Governance, Springer, Switzerland.

Flemer III, W. (1984), "Island and median-strip planting”, Arnoldia, Vol. 44 No. 4, pp. 14-28.

Government of India (2015), "Green Highways (Plantation and Maintenance) Policy - 2015”, available at: http://www.indiaenvironmentportal.org.in/files/file/Green $\% 20$ Highways $\% 20$ (Plantation $\%$ 20\&\%20Maintenance) \%20Policy-2015.pdf (accessed 21 June 2020). 
Gurara, D., Klyuev, V., Mwase, N. and Presbitero, A.F. (2018), “Trends and challenges in infrastructure investment in developing countries", International Development Policy, 30 November, available at: http://journals.openedition.org/poldev/2802 (accessed 20 August 2020).

Haque, M.N., Mamun, M.A., Saroar, M.M. and Roy, T.K. (2019), “Application of 'DPSIR' framework to assess the status and role of Blue Ecosystem Services (BES) in Khulna City", Journal of Engineering Science, Vol. 10 No. 2, pp. 49-60.

Harriss, J. (2000), "Working together: the principles and practice of co-operation", in Robinson, D., Hewitt, T. and Harriss, J. (Eds.), Managing Development: Understanding Inter-organizational Relationships, Sage, London.

Hasanuzzaman, M., Hossain, M. and Saroar, M. (2014), "Diversity and preference of agricultural crops in the cropland agroforests of southwestern Bangladesh", International Journal of Agriculture and Crop Sciences, Vol. 7 No. 7, pp. 364-372.

ILO (International Labour Organization) (2019), Independent Evaluation of ILO's Public-Private Partnerships, International Labour Organization, Geneva.

IMF (International Monetary Fund) (2009), World Economic Outlook, IMF, Washington, DC.

Joshi, A. and Moore, M. (2004), "Institutionalized co-production: unorthodox public service delivery in challenging environments", Journal of Development Studies, Vol. 40 No. 4, pp. 31-49.

Leal Filho, W., et al. (2019), "Assessing the impacts of climate change in cities and their adaptive capacity: towards transformative approaches to climate change adaptation and poverty reduction in urban areas in a set of developing countries", The Science of the Total Environment, Vol. 692, pp. 1175-1190, doi: 10.1016/j.scitotenv.2019.07.227.

Milken Institute (2014), "Industrial diversification in Bangladesh: opportunities and challenges Financial Innovations Lab Report”, available at: https://milkeninstitute.org/sites/default/files/ reports-pdf/Diversification-Bangladesh-FIL.pdf (accessed 3 September 2020).

Nguyen, D. and Garvin, M. (2016), Risk Allocation and Management Practices in Highway PPP Contracts: Pilot Study of Virginia, American Society of Civil Engineers, San Juan, Puerto Rico.

Public Private Partnership Authority Bangladesh (2019), Annual Report 2018-19, Public Private Partnership Authority (PPPA), Prime Minister's Office, Government of the Peoples Republic of Bangladesh, Dhaka, available at: http://www.pppo.gov.bd/download/ppp/ar/PPPA_AnnualReport_2018-19.pdf (accessed 24 August 2020).

Rashed, M.A., Alam, M.M. and Fahim, F. (2014), "The performances and challenges of Public-Private Partnership (PPP) projects in Bangladesh”, Journal of Bangladesh Studies, Vol. 15 No. 2, pp. 67-71.

Sajan, T., Alo, K. and Aktaruzzaman, S. (2014), "Public Private Partnership (PPP) in health sector of Bangladesh", Anwer Khan Modern Medical College Journal, Vol. 5 No. 1, pp. 42-45.

Sunam, R.K., et al. (2018), "Implementing the 2030 agenda in Asia and the Pacific: insights from voluntary national reviews", UNU-IAS Policy Brief Series, Institute for the Advanced Study of Sustainability, United Nations University, Tokyo.

The World Bank (2012), "Public-Private Partnerships (PPPs): reference guide", available at: http:// documents.worldbank.org/curated/en/203931468339053317/Public-Private-Partnerships-PPPsreference-guide (accessed 12 July 2019).

The World Bank (2013), Bangladesh: The Path to Middle-income Status from an Urban Perspective, The World Bank, Washington, DC.

The World Bank (2016), Leveraging Urbanization in South Asia: Managing Spatial Transformation for Prosperity and Livability, South Asia Development Matters, The World Bank, Washington, DC.

UNFPA (United Nations Population Fund) (2007), State of the World Population 2007: Unleashing the Potential of Urban Growth, United Nations, New York, NY.

UN-Habitat (2016a), “Urban governance, capacity and institutional development”, available at: http:// habitat3.org/wp-content/uploads/Policy-Paper-4-English.pdf (accessed 12 July 2019). 
UN-Habitat (2016b), World Cities Report 2016: Urbanization and Development, Emerging Futures, UN-Habitat, Nairobi.

United Nations (2013), Investment Policy Review Bangladesh, United Nations, New York and Geneva.

United Nations (2015), "Transforming our world: the 2030 agenda for sustainable development", available at: https://sustainabledevelopment.un.org/post2015/transformingourworld/publication (accessed 15 June 2019).

United Nations (2018), "Sustainable Development Goal 11: make cities and human settlements inclusive, safe, resilient and sustainable", available at: https:/sustainabledevelopment.un.org/ sdg11 (accessed 12 June 2019).

UNPD (United Nations, Population Division) (2018), “World urbanization prospects 2018”, available at: https://population.un.org/wup/ (accessed 15 June 2020).

WSUP (2017), Public-Private Partnerships Explained: Urban Sanitation Service Delivery in Bangladesh, Water and Sanitation for the Urban Poor, Dhaka.

\section{About the authors}

Md. Nazmul Haque is a Lecturer in the Department of Urban and Regional Planning, Khulna University of Engineering \& Technology (KUET), Bangladesh. His research interests include public administration, policy and environmental engineering. He has published in refereed journals on SDGs and Sustainable Urban Environmental Management. His recent paper has been published in the Bangladesh Army University of Engineering and Technology (BAUET) Journal. He has been awarded the university gold medal.

Mustafa Saroar is a Professor of Urban Environmental Management in the Department of Urban and Regional Planning, KUET, Bangladesh. Being an expert in the fields of Urban Management, Climate Adaptation, Disaster Risk Reduction and ICZM, he worked for many renowned international organizations including Unicef, UNDP, FAO and CGIAR Institution. He has published more than 30 peer-reviewed papers for Springer, Elsevier, T\&F, Wiley \& Sons and Emerald. His recent research article co-authored with Fatema Alves has been published in Environmental Science \& Policy. Mustafa Saroar is the corresponding author and can be contacted at: saroar.mustafa@yahoo.com

Md. Abdul Fattah is an undergraduate student in the Department of Urban and Regional Planning, KUET, Khula, Bangladesh. His research interests are public policy and environmental science toward achieving SDGs.

Syed Riad Morshed is an undergraduate student in the Department of Urban and Regional Planning, KUET, Khula, Bangladesh. He is interested in public policy research regarding Sustainable Urban Management, Environmental Engineering, GIS and Remote Sensing.

For instructions on how to order reprints of this article, please visit our website:

www.emeraldgrouppublishing.com/licensing/reprints.htm

Or contact us for further details: permissions@emeraldinsight.com 